\title{
Küreselleşme Çağında Kentsel Afetler
}

\author{
Cumhur OLCAR ${ }^{1 *}$
}

\section{Öz}

Afetlerin ekonomi ve toplumlara olan kısa ve uzun dönem etkileri yapılan çalışmalar ile ortaya konmuştur. Küreselleşmenin yaygınlaşması ile afet etkilerinde meydana gelen değişikliler küresel ve yerel ekonomilerin üzerinde etkiler oluşturmaktadır. Bu çalışma kent ortamında meydana gelen afetlerin etkilerini küreselleşme ışığında ele alacaktır. Kentler kuruldukları ilk çağlardan bu yana doğal afetlerden etkilenmiştir. Doğal faktörlere göre planlanan kentler küreselleşme çağında yeni afet çeşidleri nedeniyle tehdit altındadır. Küreselleşmenin gelişmekte olan ülkelere sağladığı kazançlar tartışılıyor olsa da, bu çalışma sanayileşmiş ekonomilerin gelişmekte olan ülkeler ile bağını kurarak afet etkilerini inceleyecektir. Afetin makroekonomi üzerine etkileri inmal edilmemeli, afet yönetimi topluma ve toplumun esnekliğine (resilience) odaklanmalıdır. Kent küçük ve sınırlanmış coğrafyalarda yaşayan topluluklara inşa edilmiş çevrelerde hizmet eden altyapıların, diğer yapıların ve binaların tümüdür. Kentli kent alanları dâhilinde ilgili sistemeler çerçevesinde kurulu sosyal işlevler tarafından desteklenmektedir. Sermaye stoku iş merkezlerini kapsayan ekipmanları, altyapıyı ve ekonomik ilişkileri yönlendiren birikimdir. Afet kent içerisinde yaşayanları ve kurulu sermaye stokunu doğrudan etkileyen sonuçları doğurur.

Anahtar Kelimeler: Afet, kent, küreselleşme, dirençlilik

\section{Urban Disasters in the Globalization Age}

\begin{abstract}
The short and long-term effects of disasters on the economy and societies have been demonstrated through disaster studies. Changes in disaster effects with the spread of globalization have effects on global and local economies. This study will address the effects of disasters occurring in the urban environment in the light of globalization. Cities have been affected by natural disasters since the first ages they were founded. Cities planned according to natural factors are under threat due to new disaster types in the era of globalization. Although the benefits of globalization to developing countries are discussed, this study will examine disaster effects by establishing the link of industrialized economies with developing countries. The effects of disaster on macroeconomics should not be neglected, and disaster management should focus on society and resilience. The city is all of the infrastructures, other structures and buildings serving in environments built for communities living in small and restricted geographies. It is the accumulation that directs the equipments, infrastructure and economic relations that include capital stock business centers. Disaster has consequences that directly affect urban residents and established capital stock.
\end{abstract}

Keywords: Disaster, urban, globalisation, resilience.

\section{KENT VE KENTSEL AFETLER}

Toynbee kent tarihinin yaşayanların aralarında kurduğu ilişkilerin bir parçası olduğunu görmüştür. Kent yaşamı politika, ekonomi ve doğa çerçevesinde kentliyi özgür bırakan süreç ve kuvvetler tarafından belirlenen olayların tümüdür. Kentin bölünmez bütünlüğü kent öncesi

\footnotetext{
${ }^{1}$ Ankara Hacı Bayram Veli Üniversitesi, Siyaset Bilimi ve Kamu Yönetimi Anabilim Dalı, Ankara, Türkiye İlgili yazar / Corresponding author: cumhurolcar@gmail.com
} 
yerleşkelerin geçici ilişkilerinden tutun da günümüzün değişmez bilişim ve iletişim ağına varana dek ortaya çıkan deneyimlerin tamamının bir ürünü olarak karşımıza çıkmaktadır. Öyleyse kenti anlamımızda bazı öncelikler öne çıkmaktadır. Kentte meydana gelen sosyal ilişkilerin zamanla ve mekana göre nasıl değiştiği çağımıza değin önemlidir. Bu değişimin meydana getirdiği farklılıklar esas alındığında kentin değişen faaliyet yapısı nelerdir? Faaliyetlerin neticesinde kent içerisinde ve kentler arasında sonuç olarak karşımıza çıkan üretim ve sosyal ilişkilerin neler olduğu ayrıca mühimdir (Rivet, 1973: s. 41). Bu öncelikler sonucunda meydana gelen değişimler araştırıldığında görülecektir ki kent sosyal ilişkileri meydana getiren insanların mekân içerisinde meydana getirdiği cemaat duygusu ve heyecanıdır. Ve kenti meydana getiren ve güncelleyen bu duygu ve heyecan bütünlüğünün ta kendisidir (Geddes, 1949: s. 123).

Kenti oluşturan nüvenin desteklediği keskin değişimler insan yaşamının mihenk taşlarını ortaya koymaktadır. Gordon Childe ve ürettiği 'Neolitik Devrim' yaşayanların hangi aşamaları tamama erdirerek günümüze hayat veren kent ortamını oluşturduklarını bizlere gösterir. Kenti meydana getiren duygu ve heyecanın bizleri nasıl avcı-toplayıcı bir cemaatten tarımsal bir oluşuma dönüştürdüğünü ve sonrasında yaratıcılığımızı kullanarak nasıl üreten bir topluma evrildiğimizi anlamamız gerekmektedir. Çatal-Höyük ve öncesinde Göbekli Tepe'de karşımıza çıkan bulgular cemaat birlikteliğinin ve toplumsal heyecanın kentin oluşumu ve gelişimi için ne kadar önemli olduğunu bizlere göstermektedir (Schmidt, 2012: s. 11).

Kent tarihi içerisinde gerçekleşmiş evrimsel süreç yaşayanların ilişkilerinin birbirine bağlandığı ve kültürel değişimlerin içerisinde gerçekleşmiş bir döneme işaret etmektedir. Yaşayanlar düşünsel yetilerini kullanarak zamanla bedensel faaliyetlerine yeni görevler yüklemiş ve doğan kültür etrafında yaratıcılıklarına ve üretkenliklerine devam etmişlerdir (Childe, 1948: s. 25). Kent doğanın bir yansıması olarak doğanın içinden doğmuştur. Doğaya hükmetmeyi öğrenmiş insan nasıl kendini idame edeceğine dair faaliyetleri geliştirerek kent yaşamının başlamasını sağlamıştır. Bu idame yeteneği ilk devrimi meydana getirmiştir. İnsanlık gıda zincirini kurmuş ve doğa içerisinde kent ekolojisini oluşturmaya başlamıştır. Canlılarla iletişimini kesmemiş, besin zinciri içerisinde canlılara yer verirken üretim harici faaliyetler içinde onlardan yararlanmaya başlamışlardır. Bunun adı neolitik devrimdir (Childe, 1948: s. 66). Yaşayanlar yoğun faaliyet içerisine girmiş ve organizasyon yetilerini yükseltmişlerdir. Düzen şehir yaşamının bir parçası haline gelmiştir. Kültürel olarak düzene giren faaliyetler sadece güncel yaşam konuları üstüne değil ayrıca astronomi gibi konulara da değinmeye başlamıştır. Aslında güncel yaşam ile evrenin arasındaki bağlantı çözülmüş ve bu konu üzerine yapılan deneysel yaklaşımlar artmıştır. Kent sadece üretim merkezi olarak değil ayrıca düşünsel ve deneysel manalarda da yaşamın odak noktası olmuştur. Bunun adı kentsel devrimdir (Childe, 1948: s. 140).

Kentsel devrim toplumun inşası manasına da gelmektedir. Toplum yaşayan için şarttır. Yaşayan kendi besinini sadece kendisi üretmez. Desteğe intiyacı vardır. Dahası üretim için iş bölümüne ve faaliyet planına ihtiyaç duyulmaktadır. Tarımsal üretimi var edecek ve kolaylaştıracak sanayi de kurulmalıdır. Bunun yanı sıra korunma ve barınma diğer intiyaçlardır. Toplum işçi, bekçi, yönetici ve öğreticilerden oluşmak mecburiyetindedir. Böylece ekonomi oluşur ve artı değer üretimi başlar. İnsan yaşamı gelişir ve kolaylaşır. Kent böylece kendi coğrafyasını yaratır. İçinde doğduğu iklim ve coğrafya önemlidir lâkin kendi ekolojisi oluşmaya başladığı anda kentin yaşam çizgisi değişir. Sosyal yapılar kurulmaya başlanır. Cemaat yapısından toplum yapısına bir geçiş söz konusudur. Gelenekler oluşur ve yaratıcılıkla kültür şekillenmeye başlar. Kültürel yapı egemenlik evrelerini şekillendirir ve siyasal yapılar kurulmaya başlanır. Devlet kurumu ortaya çıkar. Toplum ve ümran arasındaki bağ kalınlaşır. Toplumsal yaşam ve uygarlık bayındırlık faaliyetleri ile uzun soluk kazanır. Ümran kavramı yerini bulur. Kurulan ilişkiler kent içerisinde gerçekleşir ve kentin geleceğine 
yön verir. Yeni ilişkilerin evi haline gelir. Cemaat içerisinde meydana gelen asabiyet bağı yerini yavaşça kentli ilişkisine vatandaşlık bağına dönüştürür (İbn-i Haldun, 2013: s. 31).

Kenti kuran toplumun üç evresi vardır. İlkel yaşam dönemi, devlet kurma dönemi ve kentsel yaşam dönemi. İlkel dönemde kent yeni şekillenmekte insan kabile ortamı içerisinde yaşamaktadır. Gelenekler ve temel gereksinimler oluşmuş fakat yasalaşma gerçekleşmemiştir. Devlet döneminde kent oluşmuş ve gelenekler kültüre dönüşmüştür. Bilim, sanayi ve yaratıcılık gelişmiştir. Çevre, kültür ve şehirler ile etkileşim başlamış ve hatta hakimiyet dönemine girilmiştir. Yasalar kent yaşamı için temel hale gelmiş düzen kurulmuştur. Kentsel dönemde ise yerleşik hayat gelişmiş kurumlar oluşmuştur. Kentler sadece kendi kültürlerini değil diğer kültürler ile kurdukları bağ sayesinde başka gelenekleri ve gelişmeleri de izler ve uygular hale gelmişlerdir. Zenginlik artar. Yaratıcılık gelişir. Eğlence ve sosyal hayat çeşitlenmiştir. Bilim ilerlemiş kültür ziyadesiyle parlamıştır (Ibn-i Haldun, 2013: s. 31). İnsan doğuştan uygardır ve bu nedenle kent doğuşundan itibaren yaşayanların bir ürünüdür. Toplumsal yaşam insanlar için kaçınılmaz sondur ve bu nedenle kentsel yaşam yaşayanlar için elzemdir. Ümran kent yaşamıdır ve kent bizatihi toplum içerisindeki insanın ta kendisidir (İbn-i Haldun, 2013: s. 121).

Toplumsal yaşamın kurduğu ve geliştirdiği kent yaşamı ne yazık ki tehditlerle doludur. Doğal felakaetler bunların başlıcaları arasında bulunur. Kentlerin kuruldukları ve yayıldıkları zemin ve çevresel faktörler kentlilerin yaşamlarını doğrudan etkiler. Kentlerin yok olmasında bazen doğal felaketlerin rolü büyüktür. Küreselleşme çağında dahi bugün bizler çarpık kentleşmenin sebep olduğu felaketler ile yüzleşmek mecburiyetindeyiz. Kentlerin yayılımı ve büyümesi sağlıklı şehir planlaması yapılmayan kentler için afetlerin neden olacağı sorunlar manasına gelmektedir. Deprem, sel, yangın ve kasırga kentlerin günümüzde yüzleştiği kentsel afetlerden sadece birkaçıdır. Kentleri oluşturan toplumsal yaşam kentlere küreselleşme çağında bir başka afet çeşidini daha litaratüre eklememiz gerektiğini anlamamıza neden olmuştur: Terörizm. Kentlerin olağan yaşamına sekte vuran ve dehşet verici psikolojik sonuçlar yaratan terör eylemleri neden kentlerimizin tasarımının afetlere yöenlik olması konusunda yeni anlayışlara ihtiyaç duyduğumuzu bize göstermektedir (Pelling, 2003; Filion, 2015; March ve Kornakova, 2017).

Kentsel afetler kenti, kentliyi ve ilgili sosyo-ekonomik aktiviteleri tehdit eden olayların tümüdür. Şayet risk büyük kentleri tehdit etmekteyse, risk kentin sınırlarının ötesine taşmakta ve dışarıdaki bölgeleri de etkilemektedir. Tartışmalar büyük afetler etrafında dönmekteyse de, hafif hasar bırakan ve kolaylıkla kontrol altına alınan küçük afetlerde tartışma alanına girmektedir. Öncelikle, afet etkilerinin ortalama gayrisafi yurt içi hasılayı dahi aşmadığı kayıpların ve kentin ekonomik faaliyetlerine zarar veren olayların neticesi incelenmelidir. İkincil olarak, tepkisel olarak afetlerin önemli bir bölümünün coğrafi ve ekonomik olarak yerelleşmesi ve ekonomi üzerine olumsuz sonuçları ele alınmalıdır. Üçüncül olarak, doğal (deprem, sel vs.) ve teknolojik afetler (mühendislik, biyolojik vs.) doğası gereği ani olarak meydana geldiği için afetin oluşmasından sonra gelişen kurumsal yetersizlikler ve başarısızlıklar açıklanmalıdır. Ani olarak meydana gelen teknolojik afetler sınırlanmış küçük alanlarda ortaya çıkıyor olsa da genellikle kentin tümüne hatta kentin sınırları dışına etki eden bir hal almaktadır. Afetin doğrudan etkilerine müdahaleler genellikle aynı olsa da verilen tepkiler değişmekte, kurumsal ve politik süreçlerin etkileri afete verilen tepkiyi çeşitlendirmektedir (Rossi, 1982; Smith, 1992).

Kent içinde meydana gelen kentsel doğal afetler ve teknolojik afetlerin uzantıları sanayi ve hizmet sektörlerine hafif doğrudan etki bırakmaktadır. Konut alanları genellikle afetin yarattığı darbenin, zararın ve yıkımın tamamından etkilenmektedir. Eğitim ve sağlık servisleri gibi sosyal sermaye genellikle afetin zararından ve yıkımından doğrudan etkilenmekte, yüksek olumsuz neticelere maruz kalmaktadır. Servis kaynaklarının ve servis ağının afetlerin zararından etkisi yüksek düzeylerde ve kısa süreli olmaktadır. Kentin sosyal altyapısı, ulaşım 
sistemleri, su dağıtım şebekeleri ve kanalizasyon sistemleri afetin olumsuz sonuçlarından doğrudan etkilenen birimlerdir. Kentin en tehlikeli zeminlerinde kalitesiz malzemelerle inşa edilmiş bölgelerinde yaşayan kentin fakir kesimleri maddi kayıplardan en çok etkilenen ve ölüm yahut yaralanma vakalarının daha çok görüldüğü gruplardır. Birçok aileyi etkileyen afetlerin maddi kayıpları gayrisafi yurt içi hasılanın içerisinde minimal etki yaratsa da afet sonrası afete maruz kalmış grupların ekonomik hayatlarını derinden etkilemektedir. Bu tür grupların kayıplarının telafisi genel bütçe içerisinde çok küçük pay tutuyor olsa da genellikle siyasetçilerin kararlarına bağlı olarak gelişim göstermektedir. Kentin fakir kısımlarında yaşayan ve afetten kentin diğer kesimlerine nazaran daha çok etkilenen gruplar afet sonrasını işini kaybeden kimselerin çoğunluğunu oluşturmakta, bu durum ilgili kimselerin ekonomik koşullarını daha da derinlemesine olumsuz etkilemektedir. Fakat afet sonrasında ortaya çıkan yeni istihdam olanakları sağlanmakta ve bu tür iş imkânları için ilk tercih edilen kimseler kentin fakir bölgelerinde yaşayan işsizler olmaktadır. Özellikle acil müdahale ile ilgili işler ve hasarın telafisi için artan hızda çalışan inşaat sektörü bu tür kimseler için yeni olanaklar sunmaktadır (Cochrane, 1975).

Afet sonucu meydana gelen hasar genellikle uzun vadede ekonomik düzene olumsuz etkiler yapmamakta hatta aksine canlanan bir iş ortamı sunmaktadır. Gayrisafi yurt içi hâsıla üzerine beklenen olumsuz etkiler, yatırım sınırlamaları, istihdam ve enflasyon, ticari açık ve ithalat kısa dönem içerisinde olumsuz etkiler yaratmaktaysa da iki yılı bulan bir süre içerisinde ekonomik düzelme gerçekleşmekte ve yeni ortaya çıkan inşaat ve iş olanakları ile iş piyasası kendini yenilemektedir. Afet sonrası yıkımları telafi etmek için yapılan yenileme ve yeniden inşa süreçleri kamu bütçesinden sağlanmakta fakat kısa süre içerisinde oluşan mali açık uzun süreli gelişmeler neticesinde bir sorun olarak gözükmemektedir. Sonuç olarak, afetlerin olumsuz sonuçları kalkınmanın bir sorunu olarak ortaya çıkmaktaysa da, kalkınma için bir sorun teşkil etmemektedir (White, 1974). Ancak afet sonrası canlanma genellikle Japonya gibi gelişmiş ekonomiler için daha geçerli ve etkilidir. Gelişmekte olan ülkeler için v hatta az gelişmiş ekonomik ve sosyal altyapıya sahip ülkeler için beklenen canlanma gelişmiş ekonomilerde görüldüğü kadar etkili olmayabilir.

\section{KÜRESELLEŞME VE İ̧̧ DÖNGÜSÜ}

Küreselleşme, dünyada küresel düzeyde mevcut olan rekabetçi marketlerin ve borsaların yurt içi ekonomi ile iç içe geçmesini sağlamakta, neyi? hedeflemektedir. Küreselleşme malların akışını (ticaret), sermayeyi (finans ve doğrudan), bilgiyi (şeffaflık ve erişim), işçiyi (insan kaynakları) ve kültürü (kurumsal modeller ve dinamikler) kapsamaktadır. Küreselleşmenin savunucuları ülkelerin ve ülke içi ajansların önlerindeki engellerin küreselleşme ile azaldığını, ulaşım ve bilgi maliyetlerinin azaldığını aktarmaktadırlar. Küreselleşmeye dâhil olan tarafların dünya arenasına daha etkin ve yaygın bir hâkimiyetle dâhil olduğu ve küreselleşmenin bu aktivitelerden faydalandığını söylemektedirler (Nayyar, 2002).

Diğer bir yandan, karşıt görüşlü olanlar, küreselleşmenin ekonomik bütünleşmenin faydalarını kabul etmekle birlikte yürüttüğü politikaların yanlışlığına dikkat çekmektedirler. Küreselleşme sonucu hızlı, düzensiz ve sosyal bütünlüğü sağlanamamış sürecin özellikle gelişmekte olan ülkelerde ikamet eden hassas grupların ve bu gruba dâhil kimselerin çektiği sıkıntılara etkisi nedeniyle küreselleşmeye karşı endişeler artmaktadır. Bu nedenle, küreselleşme doğrultusunda yapılan reformların hızı, içeriği ve dönüşümü geçiş sürecinde fakirliğin artmasına, eşitsizliğin büyümesine ve sosyo-ekonomik kararsızlığın oluşmasına neden olmaktadır (Nafziger and Vayrynen, 2002). 
Ekonomik döngü gayri safi yurt içi hasılada meydana gelen artış veya düşüşlerin silsilesi nedeniyle sosyo-ekonomik ve sosyo-politik etmenlerin oluşan beklentilerin ekonomik şok ve istihdam üzerinde gözlemlenen oynamaları olarak tanımlanabilir. Serbest ekonomiye sahip gelişmekte olan ülkelerin OECD ile yaptıkları ortaklık eşzamanlıdır ve ekonomik ortaklıklarını çeşitlendirebilmeleri zamanla mümkündür. Bu değişim teknik olarak tek ortaklı çalışmaların hassas dengelerine olumlu yansımıştır. Küreselleşme aynı kararlılığı, ihracatı ve piyasa şeffaflığını sağlayabilir. Piyasa içindeki bu çeşitlenme ve eşzamanlılık küreselleşme ile artabilir ve birçok ülke birbirinin ihraç ürünlerine bağımlı hale gelebilir. Bu nedenle gelişmekte olan ülkelerin kentlerinde meydana gelen bir afet iç piyasanın dışa olan bağımlılığı nedeniyle beklenenden daha derin yansıyabilir ve hatta diğer ülkelerin ekonomilerine de sıçrayabilir (World Bank, 2001).

\section{KENTLERI ETKILEYEN AFETLER}

Afet durumu bünyesinde üç bağımsız etkeni birleştiren analitik bir sistemdir. Bu üç etmen şunlardır; afet etkisi, afete karşı tepki ve bu iki etmenin neticesinde oluşan toplumsal müdahale. Bu nedenle, küreselleşme ve eşzamanlı iş döngüsü afet durumunun her bir etkenine tesir etmektedir. Potansiyel etkiler bu üç tür etkenin incelenmesi ile bulunabilir. Kim? Yaşayan bir organizma olarak toplumun doğası gereği afetlere tepki vermektedir. Kişisel ve toplumsal tepkiler organize kuruluşların aracılığıyla olabileceği gibi afeti takiben doğal olarak da meydana gelebilir (Albala-Bertrand, 1993a).

Afet darbesi zarara, yıkıma, sosyal sistemin ayrışmasına ve sosyal olarak dengesiz tansiyonlara sebep olan fiziksel sonuçlardır. Doğal afetler örneğinde olduğu gibi, büyük ölçekli doğal olaylar karşısında sınıfta kalan planların oluşturduğu sosyal süreçler ve fiziksel yapıların zayıflıkları dengesiz tansiyonların sebebidir. Pek mümkün gözükmese de toplumun bilinci dâhilinde olmayan doğal afetlerin karşısında fiziksel dayanıklılık jeofizik fenomenlerine karşı duramayabilir. Afetlere karşı direnç afetlere karşı durabilecek teknolojinin üretimine ve bu kaynaklara toplumun sosyo-politik ulaşım imkânlarına bağlıdır. Teknolojik başarısızlıklar riskli teknolojileri kullanan ve güvenli üretim yapan kurumların sorumluluklarını yerine tam olarak getirememesine bağlıdır. Kurumların bu başarısızlıkları hassasiyeti (vulnerability) göz önüne taşımaktadır (White, 1974).

Genellikle, hassasiyet (vulnerability) fiziksel ve sosyal yapıların şiddet eylemine maruz kalmasıdır. Şiddet eylemine maruz kalma ilgili risklere karşı başarısızlığın bir sonucudur. Sonuç olarak sosyal hassasiyet (social vulnerability) organize olmuş kimselerin yahut kurumların şiddet ve büyük olaylar karşısında maruz kaldıkları durumu tanımlamaktadır. Doğal ve teknolojik felaketlere karşı hassasiyetin ana faktörleri güvenilir olmayan yaşam alanları (inşa kalitesi ve arazi) ve güvenilir olmayan ekonomik faaliyetlerdir (mühendislik kalitesi, arazinin konumu ve riskli süreçler). Afet esnasında en fazla yıkıma neden olan ana sosyal faktörler ise hak erozyonu (ekonomik ve politik mülkler, erişim ve haklar), çevresel bozulmalardır (kirlilik ve aşırı kalabalık olma) ve cinsiyet özellinde ortaya çıkan ancak çeşitlenmiş kültürel bozulmalardır(White, 1974; Fatemi, 2017).

Kırsal ya da kentsel alanlar içindeki yoksulluk politik etkinliğin ve ekonomik alternatiflerin yokluğundan kaynaklanmaktadır. Artan hassasiyet ve afet riski toptan yapılmış politika ayarlamalarının neticesine ve farklı topluluklardaki küreselleşme süreçlerine bağlı olarak ortaya çıkmaktadır.

Afet türlerinin hepsi için geçerli olmak üzere, afetin etkisi oluştuğunda iki tip etki meydana gelmektedir. Bunlar, doğrudan (durağan) etki ve dolaylı (akışkan) etkidir. Doğrudan etkiler nüfusa (yaralanma ve ölümler) ve fiziksel yapıya (zarar ve yıkım) darbe vurmaktadır. Doğrudan etki ise mevcut yapılı çevrenin ve içerisinde yaşayan nüfusun dolaylı etkilendiği 
olayların neticeleridir. Bu iki tip etki toplumun durağan ve dinamik yapısında kayıplara neden olmaktadır. Sosyal olarak meydana gelen afetler, karışık acil durumlar ve teknolojik felaketler haricinde üçüncü bir etki daha vardır. Yıkıcı çöküntülerin tetiklediği hassasiyetler organize kurumların başarısızlıkları sonucu meydana gelen kurumsal etkileri oluşturur (Weiss, 2002).

Dolaylı etkiler ev halkının koşullarını (evsizlik, yerinden edilme vs.), sağlık koşulları ve toplumun beslenmesi (çevresel bozulma, hijyen sorunları, hastalık artışları, gıda kıtlığı vs.), ekonomik döngü (piyasaya olan etkiler, politikalar, beklentiler vs.) ve toplumsal aktiviteler (borçlanma, devamsızlık, bölünme, politikleşme vs.) olarak dört farklı birime ayrılmaktadır. Birbirinden bağımsız olan bu farklı birimlerden ikisi toplumu dolaylı sosyal sistemi ise doğrudan etkilemekteyken diğer ikisi temel ihtiyaçlar ve refahın oluşturduğu yaşam koşullarını doğrudan etkilemektedir. Bazı niteliklerle beraber bu genel etkiler tüm afetlerin ortak etkilerini oluşturmaktadır kaynak?

Dolaylı darbeler düşünüldüğünde, olası etkiler afetlerin daha olağanüstü olarak meydana gelmesiyle ilişkilidir. Özellikle kentsel alanlarda, doğrudan etkiler hassas sosyal yapıyı etkilemekteyken afetlerin etkilerinin uzun süreli olumsuzluklara neden olduğuna dair pek fazla kanıt bulunmamaktadır. Afetin potansiyel etkileri sadece kısa süreli olmadığı gibi acil önlemler etkisiz bir müdahale olarak da düşünülmemelidir. Sadece etkili acil durum tepkileri oluşacak olumsuz etkilerin ve toplumun rahatsızlığının giderilmesini garanti edebilir.

Küreselleşme kentsel alanlarda yukarıda bahsedilen etkileri nasıl etkilemektedir? Öncelikle, kentsel afetler tarım, madencilik ve balıkçılık gibi faaliyetlere bağlı olan gelişmekte olan ülkelerin ihracat faaliyetlerini güçlü olarak etkilememektedir. Kentsel afetin etkileri doğrudan olmamakta ve dolaylı etkilerin de kısa dönem içerisinde güçlü etkilerinin olduğuna dair az belirtiler mevcuttur (Weiss, 2002; Albala-Bertrand, 1999; Chang, 1996). Şayet küreselleşme şu anki faaliyetleri sürdürmeye devam ederse, küreselleşme sürecine dâhil olan ülkelerin şu an sahip oldukları inracat dallarına kıyasla daha birincil üretime bağlı olacakları tahmin edilebilir. Mevcut bu bağlar olduğu gibi devam ederse, küreselleşme afetlerin doğrudan ve dolaylı etkilerini sınırlamakta ve özel yahut kamu binalarında, yapılarında ve donanımlarında etkinin azalmasını sağlayabilmektedir.

Yapılı çevrelerin fiziksel hassasiyetlerini azaltacak ana mekanizma bina kodları, arazi kullanımı kısıtlamaları ve riskli teknolojilerin belirlenmesi gibi düzenlemelerdir. Bu alandaki düzenlemelerin tecrübeleri sonucunda düzenlemelerin daha etkili olabilmeleri yasamaya ve şeffaflığa bağlıdır. Küreselleşme ile en iyi örnekler konusunda artan bilgi birikimi, afet ile ilgili yasamaların en iyi haliyle yürürlüğe konulmasına vesile olacaktır. Küreselleşme ayrıca artan oranda açık toplum ve gelişen şeffaflığı üstlenmekte, yasamanın etkin uygulamalarıyla kontrolsüz yolsuzlukların önüne geçebilecektir. Fakat yasamanın uyarlanması ve uygulanması küreselleşmeden daha çok topluma bağlı olarak gelişmektedir (Akay, 2007; Weiss, 2002).

Yabancı finans kaynaklarının yurt içindeki kaynaklara akışı daha gelişmiş bir finans mekanizması oluşumuna katkı yapacak ve hassasiyetin dayanırlığını arttırdığı gibi risklerin azaltılmasına vesile olacaktır. Böylece maddi kaynaklara erişim ve sigorta kapsamının genişlemesi doğal ve teknolojik afetlerin olumsuz etkilerini iyileştirecektir. Bu mekanizma afet sonrası geniş iş alanlarının ve afete maruz kalmış kimselerin refahı üzerine olumlu yansıyacaktır. Küreselleşmenin olumlu sonuçlarından biri olarak sigorta kapsamları afetin olumsuz etkilerinin üstesinden gelmek için bireylerin yardımına koşacaktır. Daha önemlisi geniş sigorta kapsamı nedeniyle afetten önce inşaat faaliyetleri, yerleşkenin lokasyonu ve teknolojik kullanımlar denetlenebilecek, önleyici tedbirler alınabilecektir. Arazinin kullanımı, materyal kullanımı ve yapının tasarımı denetlenerek olası yolsuzlukların önüne 
geçilebilecektir. Denetimlerin süreç içinde afet öncesi takibi ve disiplini sağlanacaktır. Sonuç olarak küreselleşme desteklediği mekanizma ile afetten korunma yolları ve riskin dağılımı konularında bireylerin ve kurumların işleyişini rahatlatacaktır (Chang, 1996; Davis, 1981).

Fakat sigorta kapsamının afet öncesi ve sonrası olumlu etkileri sigorta kapsamına girecek olan kimselerin ekonomik imkânlarına bağlı olarak gelişecektir. Şu anda sigorta kapsamının avantajlarına intiyaç duyan hassasiyeti yüksek toplum kesimlerinin maddi imkânları kendilerinin güvenceye alacak miktarlarda değildir. Bunun yanı sıra, maddi imkânlar nedeniyle sigorta yapamayanların haricinde bireylerin ve küçük şirketlerin başlarından büyük bir olay geçmemesi halinde sigorta kapsamına pek başvurmadıkları belirlenmiştir (Kunreuther, 1997; Giarini, 1984).

\section{AFET TEPKISI VE MEKANIZMALAR}

5.

Afet tepkisi, afetin darbe ve etkilerini iyileştirici karşı tepkilerin içsel ve dışsal reaksiyonları olarak tanımlanabilir. Afete karşı cevaplar afet olduğunda ortaya çıkan, darbelere karşı açıım yaparak sistematik yanıt mekanizmasını çalıştırabilen ve verilen yanıtların tasarım ölçütlerini yaratabilen faaliyetlerdir. Potansiyel afet sonrası darbelerden korunmak ve iyileştirme faaliyetlerini yapabilmek için afetin darbe etkilerine karşı türetilen telafi edici aktiviteler beklenen tepkilerin amaçlarındandır. Afetlere karşı üretilen tepkiler üç tanedir. Bunlar tepki mekanizmaları, telafi edici tepkiler ve beklenen tepkilerdir. Bunların yanı sıra, afete karşı sosyal müdahalenin değişken düzeyde verdiği tepkiler düşünüldüğünde uyarılmış girişim etkilerine odaklanmak bir zarurettir.

Tepki mekanizmaları içsel ve dışsal tepkilerin süreçleridir. İçsel tepki mekanizmaları toplumun yarattığı kurumsal organizasyonun süreçlerini ifade etmektedir. Kendiliğinden olağan olarak mevcut sistemi ortaya çıkaran mekanizmalar resmi ve resmi olmayan bir seri geri bildirimleri içeren süreçlerdir. Bunlar afete karşı refleks olarak gelişen çeşitlenmiş kurulu tepkileri içermektedir. Afetlere karşı kamu bütçesi planlanmış ve hesaplanmış tepkileri oluşturmakta iken aile dayanışması otomatik içsel reaksiyonları ifade etmektedir. Dışsal mekanizmalar düzensiz ve garantisi olmayan özel amaçları olan süreçleri içerir. Otomatik tepkilerin telafi edemediği açıkları dolduran politikaları, ölçütleri ve aktiviteleri temsil eder dışsal mekanizmalar. Uluslararası yardımı ve kurulu organizasyonların müdahalesini içeren dışsal tepki mekanizması özel ve kamusal müdahalelerin bütünüdür. Uzun süreçler ele alındığında dışsal ve içsel tepki mekanizmaları birbirinden bağımsız gelişmelerdir. İçsel tepkiler toplumun güçlü ve gelişmeye açık tutum, inisiyatif ve aksiyonlarının eğitim, politika ve sosyal etkileşim yoluyla gerçekleşmesini ifade etmekteyken dışsal müdahaleler organize olmuş ve planlanmış afet öncesi ve sonrasını ilgilendiren programlardır (Albala-Bertrand 2000a; Cuny, 1983; Davis, 1981; Quarantelli, 1978; White, 1974; Barton, 1970; Dynes, 1970).

Doğal afetlerin ve teknolojik başarısızlıkların olumsuz etkileri olası acil tepkilerin yayılımını ve kötüleşen dolaylı etkilerini içermektedir. Bu tür afetlerin etkisini giderebilmek için önemli boyutlarda kamu müdahalesi, kamu finansmanı ve yurt dışı yardımlarını gerekli kılmaktadır (Kunreuther, 1997; Albala-Bertrand, 1993a). İleriye dönük önlemler afetlerden korunma ya da koruma başarısız olduğunda devreye giren etkili sosyal müdahaleleri amaçlayan tutum ve kurumsal tepkileri ifade etmektedir. Afetin olumsuz etkilerini azaltmak ve olası riskin dağılımını sağlamak için koruma faaliyetleri sigorta, vergi sistemleri ve konut kredilerine destek olmak zorundadır (Kunreuther, 1997; Albala-Bertrand, 2000b; Giarini, 1984; Cochrane, 1975; Dacy and Kunreuther, 1969). Bu tür koruma faaliyetleri ayrıca piyasanın gözlemini, göç faaliyetlerinin takibini ve verilen tepkilerin etkililiğini ortaya koyan ve söylenti ve anti sosyal tutumları sınırlayan aktiviteleri içermektedir. 
Küreselleşme yukarıda bahsedilen mekanizmaları ve mekanizmaların etkinliğini nasıl etkilemektedir? Toplum, aile, komşuluk, iş alanları, resmi ve resmi olmayan çalışma ilişkilerini içeren belirli kişilik gruplarının bir hiyerarşisini ve sosyal etkileşimini ifade eden kurumların istikrarıdır (Stiglitz, 2002). Toplumsal afet tepkilerini geliştiren küreselleşme piyasanın daha açık hale gelmesine vesile olmakla kentteki küçük firmaların küresel firmalar karşısında haksız rekabete yol açmaktadır. Haksız rekabet koşulları resmi firmaların ve çalışanların ekonomik faaliyetlerine etki etmekteyken, gelişmekte olan ülkelerde mevcut gayri resmi piyasalara da olumsuz etki etmektedir (Thomas, 1990). Bunun yanı sıra, küreselleşme özelleştirmeyi, iş piyasasının düzensizliğini ve etkililik ve verimlilik arayan firmaların yapısını sosyal maliyeti ve gittikçe kötüleşen sosyal yapıyı göz ardı ederek gelişimini tetiklemektedir. Küreselleşme süresince yüksek istihdam ve istikrar yavaşlarken resmi ve resmi olmayan içsel mekanizmaların olumsuz ayrışmaları afetten etkilenen insanların alternatif yaşamlarını ve kamusal korumalarını zaman bakımından kısıtlamaktadır (Mansoob, 2002).

Ayrıca, küreselleşme sermayenin serbestisini sağlarken olumsuz ekonomik şokların yaratıcısı olarak düzensiz sermaye akışının karasızlığına neden olmaktadır. Süreç böyle işlemeye devam ederse kentteki yoksulluk kısa süreli bir mühlet olmaktan çıkamamaktadır. Ekonomik faaliyetlerin kötüye gitmesiyle afete karşı düzenin ve dayanaklııı̆ın azaldığı ve içsel tepki mekanizmalarının bozulduğu gözlemlenmektedir. Sonuç olarak, afet zamanı küreselleşme ekonomik düzensizliklerin ve istikrarın azalmasına neden olarak içsel tepkilerin kısıtlamakta, afet darbelerinin toplumu vurduğu anlarda iç ve dış kaynakların daha çok içsel tepkileri meydana getirmeleri için desteğe intiyaç duymaktadır.

Örneğin, şayet bir ülke yurt içi ekonomisi ve bütçesi bakımından ekonomik ve toplumsal gereksinimleri karşılamakta güçlük çekerse afetlere karşı önlemleri almak ve gerekli tepkileri vermekte gecikebilir ve başarısızlığa uğrayabilir. İdeal dünyada bu gibi durumlarda yurt içi olumsuzlukların üstesinden gelmek için yabancı kaynakların ilgili kurumlar üzerinden desteğe intiyaç duyulmaktadır. Küreselleşmenin bu gibi durumlarda devreye girebilmesi için gerekli politikaların oluşmasına gereksinim vardır ve ancak bu halde hassasiyeti yüksek kimselerin afetlerden zarar görmesi yahut zararlarının azaltıması mümkün olabilir (Mansoob, 2002).

Diğer bir yandan, eğer küreselleşme eş zamanlı iş döngüsünde durgunluğa neden olmaktaysa, geçiş sürecinde olan ülkeler bu durumdan üç şekilde etkilenmektedir. İlkin, ekonomideki durağanlık daha önceden açıklanan olumsuz durumların güçlenmesine neden olmaktadır. İkinci durum ise, ihracat talepleri, mülk fiyatları ve sermaye akışı olumsuz etkilenmekte ve yurt içi finans durumunun kötüleşmesine ve zaten bunalımda olan toplulukların daha çok zara görmesine neden olur. Netice de ülkenin afete göstereceği içsel tepki mekanizması yavaşlar yahut başarısızlığa uğrar. Üçüncül olarak, dünya geneline yayılmış ekonomik durgunluk, yurt dışı yardımların desteğinde gönülsüzlüğe neden olmakta, yardımların miktarında ve boyutunda düşüş gözlemlenmektedir. Afet sonrası yeniden inşa faaliyetleri afete dair aktivitelerin boyutunda gerginliğe neden olarak ekonomi üzerinde dolaylı yükler meydana getirir (Thomas, 1990).

Durgunlukta olan ülke yenileme ve yeniden inşa faaliyetlerine hizmet etmek için atıl sermaye kaynaklarına sahiptir. Bu gibi kaynaklar yurt içi talep yaratmakta ve afet tepkilerine yönelik yurt içi aktivitelerin sınırlanmasına değil aksine tüm ekonomi üzerine olumlu etkiler oluşmasına neden olmaktadır. Ancak ekonomi üzerine gerçekleşecek olumlu etkiler her zaman gözükmeyebilir. Afetin zararlarının üstesinden gelmek için gerekli sermaye her zaman karşılanabilir olmamakta ve hatta kısa ve orta vadede gerekli yardımın oluşmasına engel teşkil eden açıklar oluşabilmektedir. Şayet ülkenin ekonomisi açık bir ekonomi ise, yapılacak ihracatın afetten olumsuz etkilenmesi önlenebilir. Yapılacak inracat ile afetin olumsuz etkilerini ortadan kaldıracak atıl sermaye küresel bağlantılarla sağlanabilir. İhracat yapılacak 
ürünlerin küçük bir bölümü ile oluşacak yurt içi talebe cevap verilebilir ve yurt içi talebin seviyeleri bu düzlemde ayarlanabilir. Fakat ülkenin yurt içi talebine karşı böyle bir duyarsızlık afet sonrası ekonominin durumunu ve afete karşı içsel mekanizmaların oluşumunu tahmin edilenin tersine olumsuz etkileyebilir kaynak? .

Çoğu afet mevzuatı ve ayarlamaları yaşanılan büyük afetlerin sonrasında yürürlüğe konulmaktadır. Hızlı küreselleşme, şu an mevcut olan sosyal deseni istikrarsız ve akıcı hale getirmektedir. Fakat akıcılık kurumların kendini yeniden organize edebilmeleri için aynı zamanda bir fırsattır. Kararsızlık ve sonuçları kurumsal düzenlemelerin kurulumunu zorlaştırmaktadır. O nedenle otoriter yaklaşımlar öne çıkmakta fakat bu tarz yaklaşımlar hassasiyeti yüksek toplum kesimleri tarafından hoş karşılanmamaktadır (Albala-Bertrand, 1999).

Dışsal tepki miktarı bakımından görünür yahut sorumluluklarını açık bir şekilde ortaya koyan tepkiler olmamaktadır. Normalde afet sonrası toplumsal uyanış dâhilinde harcanan enerji ve gayret hafife alınmaktadır. Görünür tepkiler finans, materyal, teknik uzmanlık, işçi ve organizasyon gibi kaynakların yönetimiyle mümkün olmaktadır. Verilecek tepki için sağlanan ana kaynaklar yerli ve yabancı olabilir. Bu kaynaklar yerel ve ulusal olarak ayrıştırılabilir. İkincil olarak ise kaynaklar özel finans kuruluşları ile yapılan ikili yahut çok taraflı anlaşma olarak alt dallara bölünebilir. Her bir ülkenin bu konuda paylaştığı ortak yan ise kaynakların daha çok yerli olmasıdır. Fakat değerli uzmanlık yardımları ve finans kaynakları kimi zaman uluslararası kaynaklardan genel tepkiyi disipline etmek için temin edilebilir (Albala-Bertrand, 1993a).

Afet darbelerinin oluştuğu vakit, küreselleşmenin ulaştığı evre ve iş döngüsünün o anki aşaması finansman kaynaklarını ve mekanizmasını çeşitli yönlerden etkileyebilmektedir. Öncelikle eşzamanlı durgunluk yerel ve yerli kaynakları doğrudan etkilemektedir. Küreselleşmenin akışkanlığının ve etkinliğinin yavaşlama sebebi olan kayıt dışı ekonomi de bu süreçten etkilenmekte, iyileşmeyi bozmaktadır. İkincil olarak döviz kurları ve yurt dışı yatırımlar etkilenmektedir. Bu gelişme aile düzeyinden başlayarak toplumun bütününe yansıyan ve iyileşmeyi olumsuz etkileyen bir düzeye ulaşabilmektedir. Üçüncül olarak ikili veya çok taraflı kaynaklar toplumun ve ekonominin durgunluğunu önleyici etkiler yapmakta yetersiz kalmaktadır. Dördüncü faktör olarak, yapılan çeşitli türdeki bağışlarla faaliyetlerini sürdüren STK'lar gelmektedir. Ekonomik alanlarda ve toplumda meydana gelen durağanlığın ardından STK'lar faaliyetlerini yürütmekte zorluk çekmektedir. Son olarak, uluslararası özel finansman kaynakları likidite sorunu için başvurulan kolay fakat riskli bir borçlanma olarak gözükmektedir. Bu tür desteklerden faydalanmak kısa süreli ferahlatıcı etki yaratabilir ancak uzun dönemde tersi bir hal alabilmektedir (Kunreuther, 1997; Albala-Bertrand, 1993a).

Afet sonrası tepkisel olarak uygulanacak politikaların toplum ve toplumun faaliyetlerini düşünülerek yapılması halinde makroekonomi kentsel afetlerden çok olumsuz etkilenmemektedir. Uluslararası tepki organizasyonları afet sonrası oluşacak olumsuz gelişmeleri telafi edici çalışmalara dâhil olabilir, tepki mekanizmalarının iyi işlemesini sağlayabilir. Fakat uluslararası kurum ve organizasyonlara ülkenin sosyo-politiği düşünüldüğünde bazı tepkiler oluşabilir. Bu gibi tepkilerin önüne geçebilmek için küreselleşmenin hızla yayılımına yardımcı olan organizasyonlar afet sonrası oluşacak sosyal ve ekonomik sorunların iyileştirilmesini sağlayacak politika ve değişikliklere odaklanarak daha istikrarlı ve güvenli yaklaşımları afetten etkilenen toplum için tasarlayabilirler (AlbalaBertrand, 1993b).

Afet durumları bağlamında bazı sonuçları şu şekilde sıralayabiliriz. 
- Kentsel afetler büyük ve mega kentleri etkileyerek geniş konut alanları içerisinde ve kentsel altyapılar altyapılar üzerinde büyük kayıplara neden olmakta, ölüm ve yaralanmalara sebebiyet vermektedir.

- Sermaye ve yatırım kayıpları ile ölümler ve yaralanmalar afet olan bölgenin yahut ülkenin makroekonomisini olumsuz etkilemektedir. Ekonomi üzerine meydana gelen olumsuz etkilere küreselleşme sağladığı faydalar ile çözüm olabilir fakat kentsel afetlerin etkisine maruz kalmış her insanı ve faaliyeti etkilemesi mümkün değildir.

- Küreselleşme sağlayacağı iş birlikleri ile afetin meydana geldiği bölge için risk faktörlerinin azaltılmasında ve korunma yollarının artırılmasında önemli bir fırsat olabilir. Ancak olası fırsatlar afetin meydana geldiği toplumun yapısına ve küreselleşmenin kendi iç mekanizmasına bağlı olarak gelişmektedir.

- Küreselleşmenin olumsuz etkileri afetin kurbanı kimseler ve organizasyonlar üzerinde ciddi olumsuzluklara sebebiyet verebilir. Özellikle dışsal tepkiler üzerine zarar verici sonuçlar doğurabilir.

\section{BÜTÜNCÜL RISK YÖNETIMI VE KÜRESELLEŞME}

Malların, hizmetlerin ve sermayenin artan küresel eldeğişimi günümüz iş ortamının önemli karakterlerinden biridir. Uluslararası firmalar açık ekonomilerin serbestisinin sunduğu fırsatları değerlendirmek için yarışmaktadırlar. Aynı zamanda devletler de uluslararası firmaların kendi sınırları dâhilinde yatırım yapmaları için rekabet halindedirler. Ekonomik büyümeyi kurmak ve sürdürebilmek için uluslararası ticarete, ybancı doğrudan yatırımlara ve küreselleşmeye intiyaç vardır. Bu nedenle gelişmekte olan ülkeler küreselleşmenin sunduğu fırsatlardan yararlanmak için küresel piyasalarla işbirliği içine girmeye çalışmaktadırlar.

Kentsel afetlerin sıklığı ve şiddeti dünya genelinde artmaktadır. Yerel risk transferlerinin genelde zayıf olduğu gelişmekte olan ülkelerde kentsel afetlerin yarattığı ekonomik kayıplar artmaktadır. Kentsel afetlerin olumsuz sonuçları az gelişmiş ekonomiler üzerinde daha yıkıcı etkiler yaratmakta, ülkenin rekabet imkânlarını kısıtlamaktadır. Gelişmekte olan ülkelerin afet sonrası sıkıntılarını giderici risk yönetim stratejileri küresel ölçekte gelişmeli, bütüncül bir yaklaşım sunmalıdır.

Kentleri doğrudan etkileyen doğal afetler kentleri ve kentin üretimi üzerine olumsuz ekonomik darbeler vurmakta, kasırga, sel ve depremler kentteki yerleşkeler ve kentin ekonomik faaliyetlerine zarar vermektedirler. Doğal afetler sonucu doğrudan kayıpların miktarı 700 milyar doları bulmaktadır. Bu kayıpların önümüzdeki yirmi yıl sonrasında 6 ila 10 trilyon doları bulması beklenmektedir. Geçtiğimiz on yıl boyunca doğal afetler 800 bin ölüme sebep olmuş, dünya genelinde kentlerde yaşayan 2 milyar insanı etkilemiştir. Oluşan ekonomik kayıpların yüzde altmıştan fazlası gelişmekte olan ülkelerden gelen zararlar olmaktadır. Oluşan kayıpların yapılmış sigortalar ile telafisi gelişmiş ülkelerde yüzde ellileri bulmakta iken bu oran gelişmekte olan ülkeler için yüzde beş düzeyindedir (ICRC, 2001).

Küresel felaketlerin sıklığı gün geçtikçe artmaktadır. Şehirleşmenin hızla yayıldığı dünyamızda afetlerin yaşam alanlarına etkisi de artmaktadır. İklim deseni dünya genelinde değişmekte ve kentleri etkileyen afetlerin sıklığını artırmaktadır. Artan afetler nüfusun artış gösterdiği yerleşkeleri doğrudan ve dolaylı olarak vurmakta, ekonomik faaliyetlerin durmasına neden olmaktadır (Kleindorfer and Kunreuther, 1999). Şehirleşmenin her geçen gün artması ve ekonomik faaliyetlerin yoğun nüfusa sahip yerleşkelere yerleşmesi sonucunda kenti etkileyen en ufak afet dahi kentin, bölgenin, ulusun ve hatta küresel piyasaların çalkalanmasına neden olmaktadır. 
Afetler sonucu ölüm vakalarında ve afetlerden etkilenen insan sayılarına baktığımızda gelişmekte olan ülkelerin daha hassas olduğu gözlemlenmektedir. Afet sonrası ölü sayısı 1970'ler ile 1990'lar arasında 2 milyon kişiden 800 bin kişiye düşmüştür. Yerel risk iyileştirmeleri ve afet hafifletme programları meyvesini vermekte fakat gelişmekte olan ülkeler bünyesinde gelişim yavaş ilerlemektedir. Özellikle gelişmekte olan bölgelerde hızlanan şehirleşmenin etkisi ile doğal ve kentsel afetlerden atklenen insan sayısı artmış, 1970'lerde 740 milyon iken 1990'larda 2 milyar seviyelerine ulaşmıştır (ICRC, 2001).

Son on yılda gerçekleşmiş afetlerin maddi zararları incdlendiğinde zararların ülkelerin gayri safi yurt içi hasılasının yüzde on ila onbeş oranında olduğu gözlenmektedir. Fakat felaket sonucu ekonomik zararların hassas olan gelişmekte olan ülkelerde dolaylı olarak arttığı bilinmektedir. Ekonomik büyüme yıllık olarak yüzde 1 ila 3 oranında duraksamakta, ülkelerin gayri safi yurt içi hasılasında yüzde beş ila yüzde on beklenmedik etiler yaratabilmektedir. Araştırmalara göre afetin olduğu sene gayri safi yurt içi hâsıla düşmekte fakat afet yılını takiben iki ila üç sene içerisinde bir artışa neden olmaktadır. Meydana gelen artışın nedenleri olarak kamusal ve özel inşaat faaliyetlerinde ki artış ve gelen yatırımlar olarak verilmektedir (Charveriet, 2000). Afet sonrası yeniden inşa çalışmaları ekonomik gelişmelerin iyileşmesine neden olmakta, verimliliği artırmaktadır (Albala-Bertrand, 1993a). Sonuç olarak şayet gelişmekte olan ülkeler afet sonrası dönem içerisinde ihtiyatlı ölçütlerle hareket eder ve afet risk finansman ayarlamalarını kurabilirse, yeni, daha etkili ve verimli bir yeniden kurulum süreci geçirebilirler.

Yapılan araştırmalara göre afetten etkilenen nüfusun oranı ile ekonomik büyüme arasında pozitif bir ilişki vardır. Bu garip ilişki önleyici risk yönetimi uygulamalarının ve risk transferlerinin yoksunluğunda, afet sonrası finansman için uygun olan acil önlemlerin alınmasıyla mümkün olabilmektedir. Bu finansman çok taraflı kuruluşların ve diğer yurt dışı yardım bağışlarıyla meydana gelmektedir. Fakat uluslararsası destekler afetten etkilenen kişi sayısı çok olduğu zamanlarda yapılmaktadır. Afetlerin yarattığı finasman kayıpları yurt dışı fnansman kaynaklarıyla giderilebilmekte ve önleyici risk yönetimi uygulamalarının afetin meydana getirdiği sosyo-ekonomik maliyetleri azaltmasına vesile olmaktadır. Risk yönetimi afetten etkilenen insanların kayıplarını azaltmakta önemli bir adım olmakta lakin politik liderler risk yönetim çabalarının genelde gereksiz maliyet yarattığını düşünmektedir. Sonuç olarak politik ölçütleri ihtiyaçlara uyarlayacak bütüncül risk değerlendirmesi, risk hafifletimi, risk transferi ve acil durumlara hazırlıklı olma gibi planlamalar yapılmalıdır (Andersen and Masci, 2001).

Gelişmekte olan ülkelerde afet sonrası ekonomik iyileşmeler çok taraflı yardım imkânlarına ve insanı yardımlara bağlı olmaktayken, daha önleyici risk yönetim yaklaşımlarını faaliyete geçirecek politik inisiyatif zayıf kalmaktadır. Bu durum gelişmekte olan ülkelerin afet sonrası ekonomik ve sosyal iyileştirmeler için daha çok uluslararası yardıma ihtiyaç duymasına neden olmaktadır. Politik liderlerin gerekli afet koruma ve hafifletme programlarını devreye sokmasına dair bir baskı olmadığı durumlarda uzun vadede uluslararası kurtarma paketlerine duyulan intiyaç artmaktadır. Fakat bütüncül risk yönetiminin uygulandığı gelişmiş ülkelerde sigorta ve alternatif risk transfer olanakları çeşitlendiği için afet sonrası meydana gelen yıkım ve kayıpların telafisi kolaylıkla bir plan doğrultusunda yürürlüğe konulabilmektedir. Bu tür risk yönetim stratejileri gelişmekte olan ülkelerde de yürürlüğe konulması elzemdir. Risk yönetimi ülkelerin afetlere olan hassasiyetini ve yeniden inşa finansmanının güvenliğini arttırmakta, afetin neden olduğu ekonomik şiddeti azaltmaktadır.

Risk yönetim yaklaşımlarının yokluğunda, gelişmekte olan ülkeler afet sonrası yıkımların telafi için geçici finansman kaynakları yaratmakta ya da mevcut fonları çeşitliendirmektedir. $\mathrm{Bu}$ tür uygulamalar uzun dönemli ekoknomik yatırımların oluşmamasına neden olmaktadır. Buna başvuran ülkeler afet sonrası kayıpların telafisi için uluslararası kredi kuruluşlarına 
başvurmakta, yabancı kaynak arayışlarına başlamaktadır. Risk yönetiminden yoksun olmak afete maruz kalan ülkelerin kısa sürede toparlanmasına engel olmakta, zaten hassaas olan ekonomik dengelerinin olumsuz yönde ilerlemesine vesile olmaktadır. Risk yönetimini gereksiz gören yönetimler yeniden inşa aşamalarını olması gerektiği boyutta ve hızda gerçekleştirememekte, sürdürülebilir bir afet sonrası planlama yapamamaktadır. Bundan dolayı, felaketin risk yönetimi yetkinlik odaklı faaliyetlere desteklemeli, böylece afetin neden olduğu ekonomik ve sosyal kayıpların telafisini hızlandırmek için uluslararası desteklere intiyaç duymalıdır.

\section{RISK YÖNETIMI VE KÜRESEL PAZAR ERIŞiMi}

Kentsel afetlerin neden olduğu doğrudan ekonomik kayıplar dâhilindeki üssel büyümeler gelişmekte olan ülkelerin gelecek ekonomik büyümeleri üzerine afetin olumsuz etkilerine tersi yönde etkileri olmaktadır. Uluslararası felekat fonlarından ve desteklerinden edinilen maddi yardımlar risk hafifletme çabalarına ve etkili olmayan afet sonrası yeniden inşa süreçlerine kötü yansımakta, manevi afetlere sebebiyet vermektedir. Afete maruz kalmış ülkelerin rekabet koşullarını iyileştirici küresel bağlantılar kontrol edilemeyen felaketin belirsizliği ile birlikte daha zararlı hale gelmektedir. Bu nedenle, gelişmekte olan ülkeler kentsel afetlere karşı daha dirayetli ve afet sonrası değişen ekonomik koşullara daha etkin cevap verebilmelidir. Önleyici risk yönetim yaklaşımları ülkelerin afetin dışsal etkilerinden ve ekonomik şoklarından daha hızlı ve etkin kurtulabilmesini sağlamaktadır.

Toplumların risk algısına bağlı olarak afete karşı hassasiyet (vulnerability) büyük ölçüde kişileştirlmiş bir görüngü haline gelmektedir. Fiyat uçuculuğu, küresel rekabet gelişmeleri ve afetlerin yıkımı gibi faktörlerin neden olduğu ekonomik tehditleri karşılamakta başarısız olan toplum afet sonrası koruma ve hafifletme planlamaların aşamalarında daha yüksek risklerle karşı karşıya kalmaktadır. Uluslararası iş ve finans kuruluşları yukarıda paylaşılan yüksek risklerin mevcudiyetini değerlendirerek yatıımlarını gözden geçirmekte yeni faaliyetlerden kaçınmaktalardır. Bu tür yatırım kayıpları ülkelerin afet sonrası ihtiyaç duydukları istikrarın temini için gerekli küresel bağlantılardan yoksunluğa ve yeni fonların ve yatırımların ülke hakkında aradıkları cazibelerin kaybına neden olmaktadır (Culp, 2002).

İstikrarlı ekonomik ortama sahip ülkeler geçici ekonomik ortama sahip ülkelere nazaran daha çok yabancı doğrudan yatırımları çekmektedir. Ekonomisi istikrarlı ülkeler uluslararası iş ortakları ile daha uzun dönemli, güvenilir ve bilgi yoğun ilişkiler kurabilmekte ve yeni iş birlikleri için daha cazip görünmektedirler. Bu nedenle afet risk yönetim yaklaşımları daha uzun dönemli iş faaliyetlerini ve sürdürülebilir büyümeyi tetikleyen rekabet koşullarını lehine çeviren bir etki olmaktadır.

Gelişmekte olan ülkeler genelde ithalat sektörlerine çok bağımlı haldedirler. Gıda ürünleri ve tarımsal ham maddeler gibi üretimlerin ekonominin yükünü çektiği ülkelerde doğal afetlerin sonucu daha yıkıcı bir hale gelmektedir. Bu gibi ülkelerde felaketler kentteki sosyal hayatı derinden etkilemekte, yoksulluğu tetiklemektedir. Belirli mallara olan aşırı bağımlılık, ekonominin esnekliğini (resilience) düşürmekte ve afetin yıkıcı etkilerininin derinliğini arttırmaktadır.

Doğal ve kentsel afetlerin ekonomiye olan doğrudan etkilerine ek olarak, afetin olduğu ülkelerde veya başka ülkelerde meydana gelen afetin arz talep dengesinde meydana getirdiği etkiler düşünüldüğünde iklimsel koşullar nedeniyle meydana gelen etkiler iş koşullarının dolaylı olarak değiştirmekte ve yönlendirmektedir. Kıtlık nedeniyle tarımsal ürünlerde meydana gelen değişiklikler afetin meydana geldiği ülkeleri olumsuz etkilemekteyken o ülke ile rekabet eden ülkeler için ekonomik birer fırsata dönüşmektedir. Bu 
durumun tersine aşırı üretim ve yahut diğer dışsal faktörlerin etkisiyle düşen fırsatlar ketler için bir başka afete dönüşmekte, ekonomik hüsran ile sonuçlanmaktadır. Ucuz üretim maliyetleri ile gelişmekte olan ülkeler ekonomik felaketten kurtulma gibi bir fırsatla baş başa kalsalarda zayıf küresel işbirlikleri nedeniyle gerekli pazarlara etkin erişimi sağlayamamakta, krizi fırsata dönüştürmekte zorlanmaktadırlar. O nedenle küresel afetlerin etkilerinden kurtulabilmek ve krizleri fırsata dönüştürebilmek için gelişmekte olan ülkelerin ham madde inracatının yanı sıra alt sektörlere ilişkin yatırımlarını artırmalı, afet sonrası dönemler için bütüncül bir önlem planı tasarlamalıdırlar. Yerel şirketler ile yabancı firmaların karışık yetenekleri ve teknolojik teknik bilgi paylaşımları artan küresel bağlarla birleştirilmelidir. Böylece afet anında yahut afetin sağladığı fırsatları değerlendirebilmek anlamında ikili ilişkiler kurulmuş, kriz yönetiminin bir başka yönü gerçekleştirilmiş olacaktır (Barton, 2002).

Rekabet merkezli ekonomik faaliyetlerin gelişimi için istikrarlı bir sosyo-ekonomik ortam yaratımı icap etmektedir. İstikrarlı sosyo-ekonomik ortamın güvenilir ve içeriği tam bir politik destekle takibi parasal ve dış ticaret dengesi ile makul olabilmektedir. İstikrarlı ortam ayrıca ülkenin bütünleştirici risk yönetim kapasitesinin kentsel ve doğal afetlerin ekonomik etkilerinden sıyrılabilme olasılıklarına bağlıdır. Ülkenin maruz kaldığı afetin dışsal şoklarından ve krizlerinden etkilenmemek için göstereceği yönetim kabiliyeti olmadan ekonomik değer yaratımı için lazım olan sürdürülebilir gelişmeyi sağlamak çok zordur. Firmalar ve devletler kendilerini kontol dışına çıkaracak veya dış kaynaklara muhtaç edecek çeşitlenmiş risklerden korumaya çalışmalıdırlar. Aksi halde firmalar ve devletler iflasın eşiğine gelmekte, bu durum firmaların ve devletlerin kaynak bulmasını zorlaştırmakta ve hatta bulunsa dahi pahalıya mal olmaktadır. Finansman konusunda meydana gelecek potansiyel kısıtlamalar ekonomi üzerine daha derinleştirici etkiler yapacak, müşteri, sağlayıcı, çalışan, işbirlikleri ve potansiyel gelecek inisiyatifleri için risk oluşturacaktır. Bundan dolayı, etkili risk transfer planlarından yoksun yüzksek düzeyde rahatsız edici iş ortamları ekonomik büyümeyi ve afetin etkilerinin ortadan kaldırmayı kısıtlamaktadır. O nedenle olası riskleri belirlemede ve yönetmede önleyici tedbirleri alma kapasitesi olmayan ülkeler modern toplulukların ekonomik başarısının arkasında olan ana unsuru göz ardı etmekte, önemsememektedir (Barton, 2002).

Risk yönetim süreçleri bir dizi ardışık görevleri kapsamaktadır; bunlar risk tanımlaması, risk ölçümü ve risk takibini içermektedir. Günümüze ait, çağdaş risk yönetim paradigması tüm risk faktörlerini ele alan ve bütünleşik süreçlerin takibini sürdüren faaliyetleri içerir. $\mathrm{Bu}$ nedenle gelişmekte olan ülkelerde risk yönetim süreci pazar geçiciliği, doğal afetler ve rekabet riskleri gibi ekonomik performansı etkileyen risk faktörlerini karılamaktadır. Farklı riskler farklı tepkileri zaruri kılmaktadır. Çeşitlenmiş ekonomik ortam rekabet odaklı üretimi dışsal ekonomik şoklara ve krizlere karşı daha esnek yapmaktadır. Bu nedenle risk yönetim süreci bir dizi ardışık adımın sürdürülmesini icap ettiren takibi gerektirmektedir. Risk yönetim sürecinin ilk aşaması mevcut ve olası her türlü risk unsurunun tespitini şart koşmaktadır. Olası risklerin hesap edilmesi ve bunlara karşı verilecek tepkinin ölçümlerindeki takip afetin ekonomi üzerinde meydana gelen olumsuz etkilerin ve iyileşmelerin takibini sağlayacaktır. Her türlü olasılığın ve süreç içinde gidişatın analizi afet risk yönetiminin olmazsa olmazıdır (Doherty, 2000). Gelir yaratımı ve ekonomik büyüme ülkede yönetilen ekonomik varlıkların rekabet edebilirliği ve küresel ekonomideki ekonomik göstergelere bağlıdır. Çeşitli doğal felaketlerden kaynaklanan potansiyel doğrudan kayıplar ileri model similasyonları ile belirlenebilir. Bu similasyonlar meteorolojik ve sismolojik olayların tarihdeki tekrarlarının bilgisini ve ekonomik altyapının karakterlerini içeren bir yapı da olmalıdır. Ayrıca ekonomil talep, yatırım faaliyetleri ve devlet finansmanlarının dolaylı etkileri üzerine ekonometrik bir model geliştirmekte mümkündür.

Ülkenin genel riskleri gelişirken politika yapıcıların birleşebilen farklı risk faktörlerinin raporlanmasını takip edecekleri bir sistemin kurulması risk yönetimi için uygun olacaktır. Değişen ekonomik altyapı, küresel pazar koşulları ve felaket sıklığını düşündüğümüzde risk 
raporları değişen şartların o anki koşullarını yansıtacaktır. Çevresel koşuların değişimi sürmekteyken, risk yönetim çerçevesi devam etmekte olan değişiklikleri yansıtacak bir yapı oluşturmalıdır. Her bir unsuru kaydetme ve niteliğini tasnif etme bilgilendirici bir yol haritası çıkarmak bakımından önemlidir. Meydana gelen ve olası risklerden kurtulabilmek çıkan sorunları çözmek için ülkenin risk silueti oluşturulmalıdır. Bu risk silueti karar vericilerin alternatif faaliyetlerini yönlendirici belirginlikte ve açıklıkta olmalıdır. Bu analitik çerçeve risklerin azaltılması için bir temel oluşturacak, risklerin transferinde ve çözümlenmesinde izlenecek yöntemlerin çıkmasına vesile olacaktır (Doherty, 2000).

\section{KAMU-ÖZEL SEKTÖR ORTAKLIĞI}

Afet sonrası iyileştirme çalışmaları için gerekli yatırımları farklı özel sektör mekanizmalarından temin etmek mümkündür. Özel sigortalar firmaların mevcut varlıklarının başına gelen zararların tamini için sigorta yapabilmekteyken firmaların yatırımları hususunda bir hizmet vermemektedirler. Bu hizmetin verilememesine neden olarak sigorta yapan ile sigorta yaptıran arasında belirli olayların nedenselliğinin açık olmaması gösterilebilir. Diğer bir yandan, sosyal sigorta programı düşünüldüğünde herbir mülk sahibinin sigorta kapsamına alındığı görülmektedir. Devlet zarar görmüş herbir mülkün zararını karşıladığından hafifletme çabalarını teşvik edici bir yapının kurulumuna intiyaç duyulmaktadır.

Maliyet-etkinlik önleyici mekanizmasına gönüllü olarak dâhil olmayan mülk sahiplerinin zorunlu hale getirilen bina kodları ile sisteme kaydedilmesi kolaylaştırılabilir. Bina kodları ayrıca kordinasyon sorunlarını çözerek kişisel mülk sahibi kimselerin kayıp azaltma ölçümlerinin adaptosyonunu sağlayabilir. Birimler arasında yayılma etkisi dışsal sebepler var ise zorunlu uygulamalara intiyaç duyulabilir. Binalar çöktüğünde, yerinden edilmenin dışsal formları ve ekonomik boyutların ötesinde acı çeken mülk sahiplerinin diğer sosyal maliyetleri meydana gelmektedir. Mülk sahipleri başlalarına gelecek bu tür sonuçları hesap edemeyebilir. Bina kodlarını haklı çıkaran özel hafifletme ölçütlerinin farkına varmayabilirler (Matsuoka ve Shaw, 2014; Shaw et al., 2016).

Gelişen ekonomiler dışa bağımlı olma sorunu gibi önemli meydan okumalar ile yüzleşmektedirler. Yapılı çevrenin afetlere karşı tasarımlarındaki yetersizlik ve gelecek kayıpları engelleyici bina kodlarını ve düzenlemeleri belirleyecek ve takip edecek personelin yoksunluğu gelişmiş ülkeleri zor durumda bırakmaktadır. Türkiye'de meydana gelen 1999 deperemleri bu tür durumlara gösterilecek doğru bir örnek olacaktır.

İstanbul yakın gelecek içerisinde Marmara Denizinde meydana gelecek büyük bir depremin etkisi altında kalacaktır. İddialar bu yöndedir. İstanbul'da yaşayan nüfusun çoğunluğunun henüz 35 yaş altında olduğunu dikkate allrsak olası depremi bu çoğunluğun deneyimlemesi muhtemeldir. Koruma ve hazırlanma faaliyetleri olamdan, İstanbullular deprem neticesinde meydana gelebilecekölümleride kapsayan önemli kayıplarla yüzleşmenin riski içerisindedirler. Hasar görebilirlik, öngörülen bir tehlikenin oluşması durumunda, bir risk unsurunda ya da risk unsuru grubunda meydana gelecek kayıp derecesi olarak tanımlanır. Nüfusun, yapıların, alt-yapı sistemlerinin ve sosyo-ekonomik yapının hasar görebilirliği kent alanlarındaki kayıplara ve deprem riskine etki eden ana faktörlerdir. İstanbul Büyük Şehir Belediyesi deprem sonrası kritik altyapıların hafifletme planlarını yapmakta, herbir evde oluşabilecek riskleri azaltmak için genel eğitimler vermektedir (IBBB, 2009; Gül ve Güneri, 2016). Fakat binlerce belki yüzbinlerce konut yapılarının yapısal kırılganlığı için atılan bir adım gözükmemektedir

Mühendislik hizmetlerinin yeterliliği sorgulanan binaların deneyimleyeceği bir sarsıntı anında zayıf yapısı nedeniyle birçoğunun yıkılacağı ve büyük bir kayıba neden olacağı 
gözükmektedir. Araştırmalara göre tehdit altında olan binaların sayısı 1.1 milyon ile 1.5 milyon arasında değişmektedir. Elbette tam bir sayı vermek mümkün değildir. Ancak afetlere özellikle de deprem afetine göre bina inşaatına dair ilk düzenlemenin 1940'lı yıllarda olduğu dikkate alınırsa tehlikenin niçin bu boyutlarda olduğu daha iyi anlaşılır. Yapılara ilişkin düzenlemeler daha sonraki yıllarda tekrar gözden geçirilmiş olsa da 2007'de resmileşen kararlardan hayli uzak oldukları açıkça görülmektedir.Yapısı biraz daha mukavemetli olan binalar ise tamamen yıkılmasa dahi ağır zarar görecek, ciddi boyutlarda can kaybına ve yaralanmalara neden olabilecektir. İstanbul ile nerdeyse benzer yapı stoğuna sahip olan İstanbul'un doğusunda bulunan şehirlerde 1999 yılında meydana gelen iki deprem ciddi maddi ve can kaybına neden olmuştur. Bu iki vahim olaydan sonra hükümet mevcut yapı stoğunu kapsayacak zorunlu deprem sigortası düzenlemesini olası yıkım sonrası yeniden inşa faaliyetlerinin maliyetini azaltmak için yürürlüğe koymuştur. Fakat bu tür yaptırımlar deprem sonrası finansal durumu iyileştirmek için yapılmışken, beklenen yatırımların güvenliği için gerekli olan yapının düşünülmediği açıktır. Türkiye ve diğer gelişmekte olan ülkelerin sıkıntısı finansman ve hafifletme ölçütlerinin nasıl tespit edileceği konusunda birleşmektedir. Dünya Bankası gibi uluslararası kuruluşlar maliyet-etki hafifletme ölçütlerini bu tür ülkeler için sağlamaktadır. Fakat gelecek olan afetlerin ülkeden ülkeye değişmesi ve dolaylı etkilerinin hesaplanamaması belli kalıptaki bu tür yardımların faydasını kısıtlamaktadır (IBB, 2012; Konukçu, Karaman ve Şahin, 2017).

\section{SONUÇ}

Kentsel afetler dikkate alındğında küreselleşme ile aralarındaki bağ ve ekonomik iç içe geçmişlik bu makale de ayrıntılarıyla ele alınmıştır. Risk yönetim mekanizmalarına değinilmiş, afet sonrası çabalara ve planlara yer verilmiştir. Günümüzde meydana gelen afetlere bakıldığında güvenlik sorunu diğer sorunlara ek olarak ortaya çıkan bir diğer husustur. Terörizmin dünyaya yaydığı endişeler dikkate alındığında kentte meydana gelen afetlerin çeşiti ve boyutu değişmektedir. Küreselleşmenin olumsuz sonucu olarak kentte meydana gelen terör olayların benzerliği ve gün geçtikçe artan tehlikesi risk yönetimi açısından dikkatle değerlendirilmelidir.

Afette maruz kalan ülkelerin koşullarına göre ihtiyaç duyduğu dış destekler bu makalede dile getirilimiştir. Fakat akla bir soru daha gelmektedir. Afet sonrası ekonomik insiyatifler için geliştirilen stratejiler içinde kamu ve özel sektörlerin rolü nedir? Önerilen çözümler afetin doğasına ve afete maruz kalan ülkenin yahut bölgenin mevcut kurumsal düzenlemelerine bağlı olmaktadır. Çözümler ayrıca gerçekleşmekte olan olayın olasılıklarına ve sonuçlarına ait bilgileri tahminlerin belirsizliği giderebilmek için talep etmektedir. Ortya çıkan sorunların çözümü nedeniyle geliştirilen stratejiler için mevcut kullanılabilir bilgilerin çeşidi değerlendirilmeli, ilgili paydaşların karar alma sreçlerinin doğası bilinmeli ve son olarak tercih modellerinin davranışları nasıl farklılaştırdığı analiz edilmelidir.

Sonuç olarak, afete karşı kaynakların etkili olarak dağılımını ve eşit değerlendirmeler yaparak dengeli bölüşümüne intiyaç duyulmaktadır. Kentlerin sahip oldukları altyapı planları mevcut kentli sayısına göre gözden geçirilmelidir. Ancak kentlerin çekeceği nüfus ve ekonomik büyklüğe göre olası afet planları kısa, orta ve uzun vadeli planlar ile güncellenmelidir. Kentlerin planlanması elbette estetik unsur taşıyan bir süreçtir. Ancak günümüzde bu değerin daha fazla artı değer kazanması için farklı disiplinlerden gelen uzmanların eşliğinde güncellencek planlar küreselleşme çağında tekrar planlamnacak kentleri afete hazır hale getirecekir. Yoksulluk sorunu ile mücadele eden gelişmekte olan ülkelerin bu planlamaya özellikle ihtiyacı vardır. Düşük gelir seviyesindeki ailelerin afetin sonuçlarını hafifletici ölçütlere nasıl ulaşabileceği ve devlet harici maddi yardımlardan nasıl yararlanacağı afet öncesinde planlanması gereken hususlardır. 


\section{Kaynaklar}

Akay, A. 2007. "Çevre Düzeni Planları ve Yetki Sorunları." Amme Idaresi Dergisi 40: 113148.

Andersen, T. J., and P. Masci. 2001. "Economic Exposures to Natural Disasters, Public Policy, and Alternative Risk Management Approaches." Infrastructure and Financial Markets Review 7(4).

Albala-Bertrand, J.M. 1993a. The Political Economy of Large Natural Disasters. Oxford: Clarendon Press.

Albala-Bertrand, J.M. 1993b. "Natural Disaster Situations and Growth: A Macroeconomic Model for Sudden Disaster Impacts." World Development 21(9): 1417-1434.

Albala-Bertrand, J.M. 1999. "Industrial Interdependence Change in Chile 1960-90. A Comparison with Taiwan and South Korea." International Review of Applied Economics 13(2):161-191.

Albala-Bertrand, J.M. 2000a. "Complex Emergencies versus Natural Disasters. An Analytical Comparison of Causes and Effects." Oxford Development Studies 28(2):187-204.

Albala-Bertrand, J.M. 2000b. "Responses to Complex Humanitarian Emergencies and Natural Disasters. An Analytical Comparison.” Third World Quarterly 21(2):215-227.

Barton, A. 1970. Communities in Disaster. A Sociological Study of Collective Stress Situations. Garden City, Ml: Anchor, Doubleday.

Barton, T. L., W. G. Shenkir, and P. L. Walker. 2002. Making Enterprise Risk Management Pay Off. New Jersey: Prentice-Hall.

Charveriat, C. 2000. "Natural Disaster Risk in Latin America and the Caribbean." Washington, D.C.: IDB.

Chang, H. 1996. The Political Economy of Industrial Policy. London: Macmillan.

Childe, V. G. (1948) Man Makes Himself. London.

Cochrane, H.C. 1975. Natural Disasters and their Distributive Effects. Boulder, CO: Institute of Behavioral Science.

Cohen, Linda and Roger Noll. 1981. "The Economics of Building Codes to Resist Seismic Shocks." Public PolicyWinter:1-29.

Culp, G. L. 2002. The ART of Risk Management: Alternative Risk Transfer, Capital Structure, and the Convergence of Insurance and Capital Markets. New York: Wiley.

Cuny, F.C. 1983. Disaster and Development. Oxford: Oxford University Press.

Dacy, D.C., and H. Kunreuther. 1969. The Economics of Natural Disasters. New York: Free Press. 
Davis, I., ed. 1981. Disaster and Small Dwelling. Oxford: Pergamon Press.

Doherty, N. A. 2000. Integrated Risk Management: Techniques and Strategies for Reducing Risk. New York: McGraw-Hill.

Dynes, R.R. 1970. Organized Behaviour in Disaster. Lexington, MA: Heath \& Co.

ECLAC (Economic Commission for Latin America and the Caribbean). 1999. Manual for Estimating the Socio-Economic Effects of Natural Disasters. Santiago, Chile.

Filion, P., Sands, G. ve Skidmore, M. (2015) Cities at Risk: Planning for and Recovering from Natural Disasters. Surrey: Ashgate Publishing Limited

Geddes, P. 1949. Cities in Evolution. London: Willıams \& Norgate Itd.

Giarini, O., ed. 1984. The Geneva Papers on Risk and Insurance. Geneva: The Geneva Association.

Gulkan, Polat. 2001. "Revision of the Turkish Development Law No. 3194 Governing Urban Development and Land Use Planning." In Paul Kleindorfer and Murat Sertel, Mitigation and Financing of Seismic Risks: Turkish and International Perspectives. Dordrecht: Kluwer Academic Publishers.

İbni Haldun 2013. Mukaddime. İstanbul, Kaynak Yayınları.

ICRC (International Red Cross and Red Crescent Societies). 2001. World Disasters Report: Focus on Recovery. Geneva.

Kunreuther, H. 1997. "Rethinking Society's Management of Catastrophic Risks." Geneva Papers on Risk and Insurance 83: 151-176.

Kleindorfer, P. R., and H.C. Kunreuther. 1999. "Challenges Facing the Insurance Industry in Managing Catastrophe Risks." In K.A. Froot, ed., The Financing of Catastrophe Risk. Chicago: University of Chicago Press.

March, A. ve Kornakova, M. 2017. Urban Planning for Disaster Recovery. Cambridge: Butterwoth-Heinamann.

Mansoob, M., ed. 2002. Globalization, Marginalization and Development. London: Routledge.

Matsuoko, Y. ve Shaw, R. 2014. Hyogo Framework for Action and Urban Disaster Resilience. Bingley: Emerald Publishing.

Nafziger, W., and R. Vayrynen, eds. 2002. The Prevention of Humanitarian Emergencies. Houndmills: Palgrave.

Nayyar, D., ed. 2002. Governing Globalization: Issues and Institutions. Oxford: Oxford University Press.

Pelling, M. 2003. The Vulnerability of Cities: Natural Disasters and Social Resilience. Oxon: Earthscan. 
Quarantelli, E.L. 1978. Disaster Theory and Research. London: SAGE.

Rivet, P. 1973. Maya Cities. London: Elek Books Limited.

Rossi, P.H. and others. 1982. Natural Hazards and Public Choice. New York: Academic Press.

Schmidt, K. 2012. Göbekli Tepe: A Stone Age Sanctuary in South-Eastern Anatolia. Heidelberg: ArchaeNova Publishing.

Shew, R. ve Parvin, G. 2016. Urban Disasters and Resilience in Asia. Oxon: ButterworthHeinemann.

Smith, K. 1992. Environmental Hazards: Assessing Risk and Reducing Disaster. New York: Routledge.

Stiglitz, J. 2002. Globalization and its Discontents. London: Allen Lane.

Stewart, F., F.P. Humphreys, and N. Lea. 1997. "Civil Conflict in Developing Countries Over the Last Quarter of a Century: An Empirical Overview of Economic and Social Consequences." Oxford Development Studies 25(1):11-41.

Thomas, J. 1990. Informal Economic Activity. London: LSE Publications.

Weiss, J. 2002. Industrialisation and Globalization. London: Routledge.

White, G.F., ed. 1974. Natural Hazards: Local, National, Global. Oxford: Oxford University Press.

World Bank. 2001. Globalization, Growth, and Poverty. Washington, D.C.. Washington, D.C. 